\title{
Lack of epithelial-to-mesenchymal transition induction in two bronchial epithelial cell lines after alpha and gamma irradiation
}

\author{
Anna Acheva, Elina Eklund, Elina Lemola, \\ Teemu Siiskonen, Virpi Launonen and \\ Meerit Kämäräinen*
}

STUK-Radiation and Nuclear Safety Authority, Environmental Radiation Surveillance, Laippatie 4, 00880 Helsinki, Finland

Email: anna.acheva@stuk.fi

Email: elina.a.eklund@gmail.com

Email: elina.lemola@stuk.fi

Email: teemu.siiskonen@stuk.fi

Email: virpi.launonen@stuk.fi

Email: meerit.kamarainen@stuk.fi

*Corresponding author

\begin{abstract}
The induction of epithelial-to-mesenchymal transition (EMT) in human lung epithelial cell lines was investigated after $\alpha$-particle and $\gamma$-radiation exposures. We applied TGF- $\beta$ treatment of cells as positive EMT-controls and tested in parallel if radiation has a potentiating effect on the EMT induction. BEAS-2B and HBEC-3KT cells were irradiated with $5.4 \mathrm{MeV} \alpha$-particles or $\gamma$-rays $\left({ }^{60} \mathrm{Co}, 1.13-1.15 \mathrm{~Gy} / \mathrm{min}\right)$ with or without of TGF- $\beta$. The cells were harvested three days post treatment and the EMT markers vimentin, fibronectin and E-cadherin were analysed by immunofluorescence staining and Western blotting. The TGF- $\beta$ treatment-induced EMT in both cell lines in the applied concentrations. We could not prove any clear EMT induction with low or moderate doses of $\alpha$-particles and $\gamma$-rays. No significant additive effect with radiation and TGF- $\beta$ was observed. We suggest that there might be a different mechanism induced by radiation in bronchial cells after radon and medical exposures that does not involve direct EMT changes.
\end{abstract}

Keywords: EMT; TGF- $\beta$; ionising radiation; bronchial epithelium.

Reference to this paper should be made as follows: Acheva, A., Eklund, E., Lemola, E., Siiskonen, T., Launonen, V. and Kämäräinen, M. (2015) 'Lack of epithelial-to-mesenchymal transition induction in two bronchial epithelial cell lines after alpha and gamma irradiation', Int. J. Low Radiation, Vol. 10, No. 2, pp.116-133.

Biographical notes: Anna Acheva, $\mathrm{PhD}$, Radiation and Nuclear Safety Authority (STUK), graduated the European Master of Science in Radiation Biology Programme at University College London and defended her $\mathrm{PhD}$ thesis at Queen's University Belfast. Her work is focused in studying the molecular mechanisms of radiation-induced carcinogenesis applying different tissue and cell culturing models.

Elina Eklund, MSc, works at Radiation and Nuclear Safety Authority (STUK), and is responsible for laboratory analyses. 
Elina Lemola, MSc, works at Radiation and Nuclear Safety Authority (STUK), and is responsible for laboratory analyses.

Teemu Siiskonen, PhD, Radiation and Nuclear Safety Authority (STUK), is the head of the laboratory of X-ray in Health Care. He is expert in nuclear physics, dosimetry and experimental irradiation systems.

Virpi Launonen, PhD, Radiation and Nuclear Safety Authority (STUK) has worked on cancer genetics and human tumour susceptibility at the University of Helsinki. Her recent scientific interests in the field of radiation biology are individual radiation sensitivity and radiation-induced carcinogenesis at low doses.

Meerit Kämäräinen, PhD, Radiation and Nuclear Safety Authority (STUK) has worked on mechanisms of cell differentiation at the University of Helsinki. At present she is interested in studying cellular effects of low dose ionising radiation and radiation induced carcinogenesis.

\section{Introduction}

The ionising radiation (IR) is a well-known human carcinogen. However, the mechanisms associated with radiation-induced tumourigenesis are poorly known. The lung epithelial cells are at risk after exposure to low and moderate doses of ionising radiation from environmental and medical sources. Radon $\left({ }^{222} \mathrm{Rn}\right)$ gas has been reported to be the second most common reason for lung cancer after smoking (WHO, 2009). According to an epidemiological European case-control study including 13 countries, about $9 \%$ of all the lung cancer deaths can be attributed to high levels of indoor radon gas (Darby et al., 2005). The carcinogenic effect of ${ }^{222} \mathrm{Rn}$, a product from the decay of ${ }^{238} \mathrm{U}$, is attributed to the emission of $\alpha$-particles. Even one single $\alpha$-particle traversal through a nucleus has the potential to cause numerous ionisations over the track, damage irreversibly DNA and trigger tumourigenesis (Hall and Giaccia, 2006). On this basis the linear non-threshold model has been adopted to predict the possible lung carcinogenic effect even with very low doses from $\alpha$-particles (National Research Council, 1999). Although the distribution of the $\alpha$-particles and the location of the highly targeted areas in the respiratory system have already been suggested (National Research Council, 1999; Szöke et al., 2012), the biological mechanisms of the very early stages of $\alpha$-particle-induced tumourigenesis remain elusive. Additionally the lung tissue may be exposed to low LET radiation during diagnostic X-ray examinations and radiotherapy (Hall and Brenner, 2008). A connection has been pointed out between the exposure to ionising radiation and development of secondary radiation-induced cancers (Inskip et al., 1994; Xu et al., 2008; Kim et al., 2013).

There is a growing body of evidence for the role of tissue microenvironment in radiation-induced carcinogenesis. Major part in this process has been attributed to the activation of TGF- $\beta$ signalling pathway (Ewan et al., 2002; Kaminska et al., 2005; Zavadil and Böttinger, 2005) which leads to a phenomenon called Epithelial to Mesenchymal Transition (EMT). EMT is described as changes of epithelial cell characteristics towards mesenchymal traits. It has a role in the organogenesis and wound 
healing, but also in disease pathogenesis such as fibrosis and cancer. The EMT hallmarks include loss of apicobasal orientation, decreased expression of adhesion molecules, matrix degradation and increased expression of mesenchymal markers (Lee and Nelson, 2012). There has been previously reported a connection between the EMT-inducing transcription factors twist, snail and zeb1 activation and the promotion of radioresistance in both non-small cell lung cancer (NSCLC) and breast cancer cells (Gomez-Casal et al., 2013; Zhang et al., 2014). Exposure of cells to IR is regarded as a sensitising factor for cells to undergo the TGF- $\beta$-induced EMT. Andarawewa et al. $(2007,2011)$ showed that a single exposure to IR sensitises the cells to TGF- $\beta$-mediated EMT. Neither radiation alone nor chronic TGF- $\beta$ secretion could induce EMT in a breast cell model. According to results of another study group (Wang et al., 2012a; Wang et al., 2012b) a mild EMT was induced after exposure of mink lung epithelial cells to protons. However, the effect was significantly enhanced with an addition of exogenous TGF- $\beta$. Moreover, the radiation-induced secretion of TGF- $\beta$ from the surrounding stroma may increase the invasive abilities of the neighbouring epithelial cells via EMT which could be one of the early stages in the radiation-activated tumourigenic changes (Barcellos-Hoff and Nguyen, 2009; Bouquet et al., 2011; Zhou et al., 2011).

In the lung tissue radon exposure directly affects the apical layers of the bronchial mucosa consisting of epithelial cells. However, little is known about the detailed mechanism of EMT within these cells. Do they produce TGF- $\beta$ and other EMT signals while targeted by radiation or do they need the presence of microenvironmental component and stromal release of TGF- $\beta$ to undergo EMT and malignant transformation? In our study we aimed to compare low $(0.1 \mathrm{~Gy})$ and moderate doses (1 Gy) of low and high LET radiation in the induction of EMT changes in bronchial epithelial cells. The used low doses were comparable to the cumulated doses from indoor radon and during medical exposures of the peripheral lung. We hypothesised that treatment with low dose radiation could activate the TGF- $\beta$ signalling pathway and induce EMT in the ionising radiation affected lung epithelial cells.

\section{Materials and methods}

\subsection{Cell culture}

Human bronchial epithelial cell line BEAS-2B was purchased from American Type Culture collection (ATCC, Manassas, VA, USA) and maintained in serum-free BEGM medium (Lonza, Walkersville, MD, USA) supplemented with Bullet Kit (Lonza).

HBEC-3KT bronchial epithelial cell line was kindly provided by Professor Jerry Shay (UT Southwestern, TX, USA). Immortalisation of the cells by ectopic expression of cyclin-dependent kinase 4 (CDK4) and human telomerase (hTERT) was described by Ramirez et al. (2004). The cells were cultured in keratinocyte serum-free medium (K-sfm, Invitrogen, Carlsbad, CA, USA). The media has been modified as suggested by the supplier. The cells were stimulated with $0.1-0.2 \mathrm{ng} / \mathrm{ml}$ recombinant human TGF- $\beta$ (R\&D Systems, Minneapolis, USA). 


\subsection{Irradiation}

$\mathrm{A}^{238} \mathrm{Pu} \alpha$-particle source $(1 \mathrm{GBq})$ was used to irradiate cells. The maximum energy of the $\alpha$-particles emitted from source is $5.4 \mathrm{MeV}$. The cells were plated either on 30 -mm cell culture plates (Corning Incorporated, New York, NY, USA) or on 12-mm MillicellPolycarbonate cell culture inserts with pore size of $0.4 \mu \mathrm{m}$ (Millipore, Temecula, CA, USA) 48 hours before irradiations. The particles passed through $100 \mathrm{~mm}$ helium, the $2 \mu \mathrm{m}$ mylar foil and $9 \mathrm{~mm}$ air before entering the apical side of the cells. The doses refer to mean absorbed dose in first $5 \mu \mathrm{m}$ of the sample.

Gamma radiation exposures were performed with a collimated ${ }^{60} \mathrm{Co} \gamma$-ray beam in $37^{\circ} \mathrm{C}$ water bath with dose rate of $1.13-1.15 \mathrm{~Gy} / \mathrm{min}$. The estimated uncertainty of the absorbed dose rate to water was $4 \%$, within $95 \%$ confidence interval (International Organization for Standardization).

The sham irradiated samples for both radiation qualities were treated as irradiated samples, except that the ${ }^{60} \mathrm{Co}$ - and ${ }^{238} \mathrm{Pu}$ - sources were shielded. Three biological replicates were collected from each dose and treatment.

\subsection{Immunofluorescence staining}

The cells were plated on membrane inserts on the day before irradiations and cultured for three days post irradiation. The cells were fixed either with $4 \%$ neutral formaldehyde (vimentin, E-cadherin, fibronectin staining) for $20 \mathrm{~min}$ at room temperature or with ice cold methanol/acetone (53BP1 staining) for $10 \mathrm{~min}$ at $4^{\circ} \mathrm{C}$. Blocking was done with $5 \%$ fetal calf serum (FCS) (GIBCO, Carlsbad, CA, USA) and 0.3\% Triton X-100 (SigmaAldrich, St. Louise, MO, USA) in phosphate buffered saline (PBS) at room temperature for $30 \mathrm{~min}$. Primary antibodies were added to the cells diluted in 1\% FCS in $0.3 \%$ TritonX100-PBS: anti-53BP1 (Novus Biologicals, Littleton, CO, USA) 1:200 and anti-vimentin (Sigma-Aldrich) 1:200 for $1 \mathrm{~h}$ at room temperature; anti-E-cadherin 1:100 (Cell Signaling, Denver, MA, USA) for overnight at $4{ }^{\circ} \mathrm{C}$, anti-fibronectin 1:20 (R\&D Systems). The incubation with secondary Alexa-488 conjugated antibodies (Invitrogen) was performed for $1 \mathrm{~h}$ at room temperature. The cells were mounted with propidium iodide containing anti-fading media Vectashield (Vector Laboratories, Burlingame, CA, USA). Imaging was performed on Zeiss AxioImager Z1 fluorescence microscopy using AxioVision image analysis software (Carl Zeiss, Göttingen, Germany).

\subsection{Western blotting}

On day 3 after irradiations the cells were lysed in buffer ( $8 \mathrm{M}$ urea, $1 \mathrm{M}$ thiourea, $30 \mathrm{mM}$ Tris, 4\% Chaps, protease inhibitor cocktail (Roche Applied Sciences, Mannheim, Germany), and $1 \%$ phosphatase inhibitor mixture (protein phosphatase inhibitor cocktail 2 and 3, Sigma-Aldrich). $10 \mu \mathrm{g}$ of protein solution was loaded per line on 4-12\% Bis-Tris Amersham pre-cast gels (GE Healthcare Bio-Sciences, Uppsala, Sweden). The separated proteins were transferred on a PVDF membrane (GE Healthcare). After incubating with blocking buffer (5\% skimmed milk, $0.5 \%$ Tween-20 in PBS or $5 \%$ bovine serum albumin in $0.75 \%$ PBS-Tween-20) for $1 \mathrm{~h}$ at room temperature the membranes were incubated with antibodies against fibronectin (R\&D Systems) 1:30 000; E-cadherin (Cell Signaling) 1:5 000; TGF- $\beta$ (Sigma-Aldrich) 1:5000; GAPDH and 
$\beta$-actin 1:50 000 (Sigma-Aldrich) overnight at $4^{\circ} \mathrm{C}$. The proteins were visualised with secondary HRP-conjugated antibodies (GE Healthcare) for $1 \mathrm{~h}$ at room temperature followed with incubation with SuperSignal ECL (Thermo Scientific, Rockford, IL, USA) and developed on X-ray sensitive film (GE Healthcare, Buckinghamshire, UK).

\subsection{Apoptosis assay}

Detection of apoptotic cells was performed using M30 CytoDEATH ${ }^{\mathrm{TM}}$ (Roche Applied Sciences) antibody against an early apoptotic marker: caspase-cleaved cytokeratin 18 epitope. The cells were stained as suggested by the manufacturer. Briefly, they were plated on membrane inserts, irradiated and fixed $6 \mathrm{~h}$ post irradiation. The cells were incubated with 1:10 dilution of the stock solution antibody for $1 \mathrm{~h}$ at room temperature. After washing the cells were incubated with 1:1000 secondary Alexa-488 conjugated antibody (Invitrogen) for $30 \mathrm{~min}$ at room temperature and mounted on microscope slides with Vectashield medium containing propidium iodide (Vector Laboratories). The slides were analysed under a fluorescent microscope.

\subsection{Statistical analyses}

The differences between the groups were analysed using a paired two- sample Student's $t$-test, part of Excel, MS Office 2003 package, with non-equal assumption of variances.

\section{Results}

\subsection{DNA damage induction after $\alpha$ - and $\gamma$-irradiations}

To validate our experimental set up and prove that bronchial epithelial cells were targeted during the high ( $\alpha$-particles) and low ( $\gamma$-rays) LET irradiation with the used doses and experimental conditions, we analysed the DNA damage induction. The chosen marker was 53BP1 foci formation. The foci levels were monitored 30-60 min post exposure of the BEAS-2B cells with doses of $0 ; 0.1$ and $1 \mathrm{~Gy}$. The $\alpha$-particles are relevant to the naturally occurring radon gas exposure whereas $\gamma$-rays are relevant to the medical exposures. The actual cell targeting by the irradiations and induction of DNA damagerelated 53BP1 foci are shown in Figure A1. The differences in foci distribution in the nuclei were evident after irradiation with both radiation qualities. The $\gamma$-ray exposures were affecting the cells with multiple but sparsely ionising secondary electron tracks and the $\alpha$-irradiations were affecting smaller percentage of the cellular population (average of 1 in 10 cells at $0.1 \mathrm{~Gy}$ and every cell at $1 \mathrm{~Gy}$ doses with one particle traversal). However, the particles are able to cause direct double strand breaks with higher efficiency and thus the cells are regarded in higher danger for transformation (Hall and Giaccia, 2006). As shown, there is a dose and radiation type-dependence in the foci formation. Multiple foci were formed along the alpha particle tracks while more homogenous distribution of foci throughout the affected nuclei was detected after the $\gamma$-ray exposure. Both effects were relevant for the type of radiation used. 


\subsection{TGF- $\beta$ induced EMT in BEAS-2B and HBEC-3KT bronchial epithelial cell lines}

To assess whether the TGF- $\beta$ treatment of bronchial epithelial cells could induce morphological changes characteristic for EMT, the BEAS-2B and HBEC-3KT cells were treated with human recombinant TGF- $\beta$ with concentrations of $0,0.05,0.1,0.2,0.4$ and 1 $\mathrm{ng} / \mathrm{ml}$ and cultured for three days. Both cell lines were monitored for morphological changes via phase contrast microscopy (Figure 1(C)) three days post irradiation. The BEAS-2B cells were also immunostained for the mesenchymal marker vimentin and analysed under a fluorescent microscope (Figure 1(A)). The intermediate filament protein vimentin is characteristic for cells of mesenchymal origin and increased expression or re-localisation is associated with EMT. As previously described by Prahlad et al. (1998), vimentin is involved in the assembly of intermediate filament networks as one of the three major systems building the cytoskeleton. During the cell re-shaping process vimentin molecules re-localise from initial spots near nucleus towards peripheral parts of cytoplasm (Figure 1(A)). These vimentin movements are characteristic for spreading cells with mesenchymal features (Prahlad et al., 1998). Clear phenotypic changes were induced in the TGF- $\beta$ treated cultures compared to the parental cells, like spindle-shaped morphology and loss of cell-to-cell contacts (Figure 1(A), 1(C) and Figure A2, the EMT cells are marked with arrows allowing to compare the shape of the cells). The EMT was also identified by analysing the TGF- $\beta$-induced changes in the expression levels of EMT associated proteins. The Western blot analyses showed that TGF- $\beta$ can induce the mesenchymal marker fibronectin expression at a concentration of $0.05 \mathrm{ng} / \mathrm{ml}$ for BEAS-2B (Figure 1(B), Figure A3(A)) and $0.2 \mathrm{ng} / \mathrm{ml}$ for HBEC-3KT cells (Figure 2(D), Figure $\mathrm{A} 3(\mathrm{C})$ ). A decreased expression of E-cadherin was observed at the concentration of $0.1 \mathrm{ng} / \mathrm{ml}$ in BEAS-2B (Figure 2(B), Figure A3(B)) and $0.2 \mathrm{ng} / \mathrm{ml}$ in the HBEC-3KT cells (Figure 2(D), Figure A3(D)). The minimal concentration of TGF- $\beta$, sufficient to induce changes both in epithelial and mesenchymal markers in each cell line $(0.1-0.2 \mathrm{ng} / \mathrm{ml})$, was chosen for the further analyses.

\subsection{Post-irradiation analyses of EMT marker expression by immunofluorescence staining}

The next objective was to assess how the radiation exposure may affect the induction of EMT-associated changes in HBEC-3KT and BEAS-2B cell lines. The cells were irradiated with $\alpha$-particles and $\gamma$-rays. Additionally we tested whether the TGF- $\beta$ has potentiated the radiation effect. The cells were irradiated ( 0.1 or $1 \mathrm{~Gy})$, treated with TGF- $\beta$ alone $(0.1 / 0.2 \mathrm{ng} / \mathrm{ml})$ or double treated (TGF- $\beta$ and 0.1 or 1 Gy irradiation) and cultured for 72 hours. The alterations in morphology were analysed by immunofluorescence stainings for vimentin (Figure 2(A), BEAS-2B cells), fibronectin and E-cadherin (Figure 2(B) and 2(C), HBEC-3KT cells). In cuboidal-shaped untreated BEAS-2B cells the vimentin is localised to a dense spot in the cytoplasm. In the TGF- $\beta$-induced cells the vimentin constitutes a clear intermediate filament network and the cells are spindleshaped. When the cells were exposed both to TGF- $\beta$ and radiation a well-defined induction of EMT was seen comparable to the cells treated with TGF- $\beta$ alone. We could not see a clear additive effect of radiation on the EMT induction. 
Figure 1 Morphological changes and expression of EMT markers in BEAS-2B (A, B) and HBEC-3KT (C, D) cells after TGF- $\beta$ treatment. Vimentin immunofluorescence stainings of untreated and TGF- $\beta$ treated BEAS-2B cells (A) demonstrated EMT associated morphological changes. Morphological changes in HBEC-3KT cells (C) are evident in the phase contrast images after TGF- $\beta$ treatment: normal cuboidal shaped cells - solid arrows; spindle-shaped mesenchymal-like cells - dashed arrows; loss of cell-to-cell contact - dotted arrows. Representative immunoblots showed increased expression of fibronectin and decreased expression of E-cadherin after TGF- $\beta$ treatment in BEAS-2B (B) and HBEC-3KT cells (D) (scale bars: $50 \mu \mathrm{m}(\mathrm{A})$ and $100 \mu \mathrm{m}(\mathrm{C})$ )
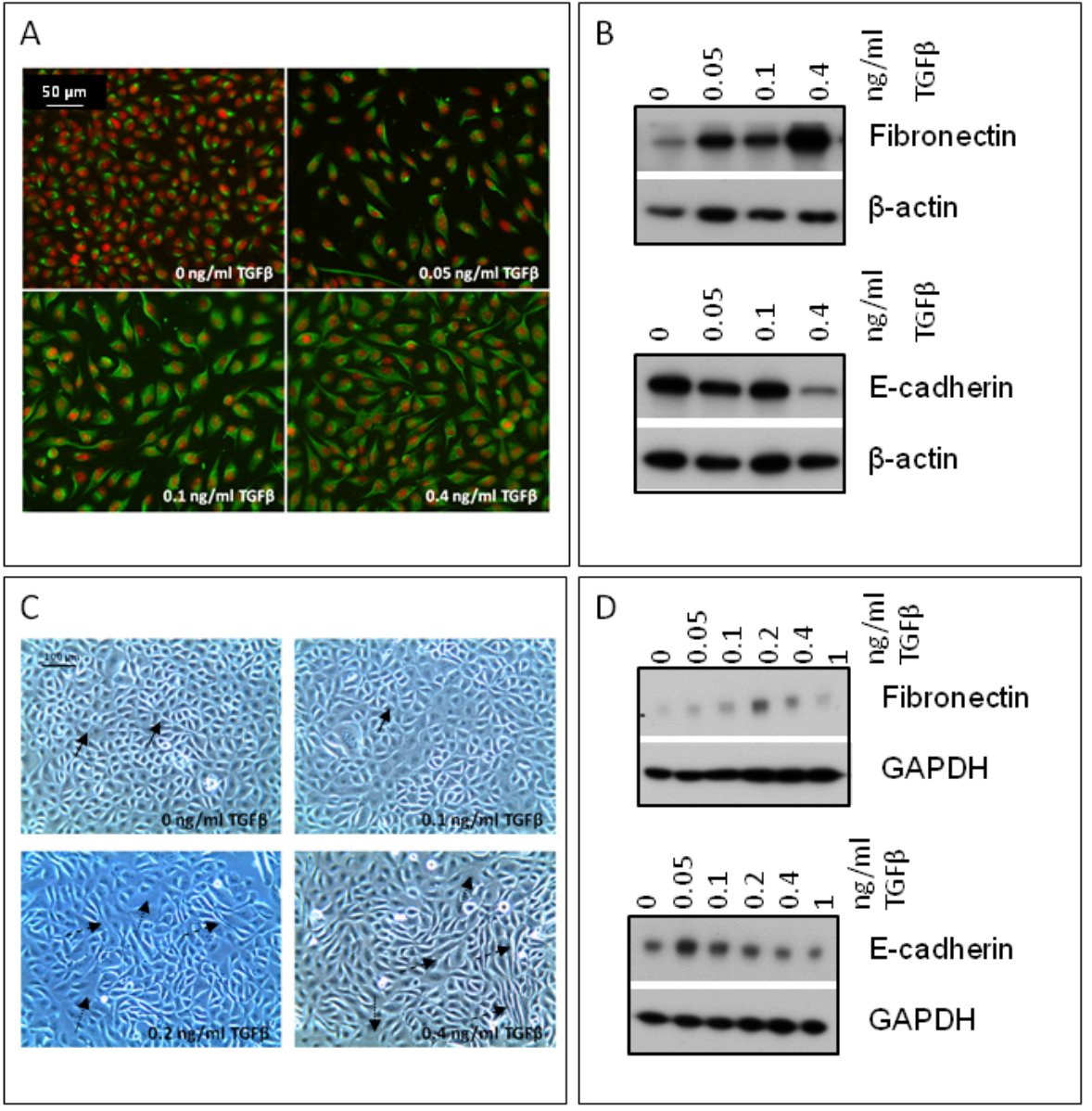

The HBEC-3KT cells were exhibiting a clear response to the TGF- $\beta$ treatment including reduction in the E-cadherin expression and increase in the cell size (Figure 2, scale bars on images allow to compare the cell size) and changes in shape from cuboidal epithelial to spindle-shaped mesenchymal. Another observation was the loss of cell-to-cell contacts which is evident on Figure 2(C) (white arrows). The radiation alone was not able to induce the EMT traits and the addition of TGF- $\beta$ stimulation to irradiated cells was not able to induce any stronger EMT induction than the TGF- $\beta$ alone (Figure 2(B)). 
Figure 2 Immunofluorescence analyses of vimentin (A) expression in BEAS-2B; and fibronectin (B) and E-cadherin (C) expression in HBEC-3KT cells post $\alpha$-irradiations $(0.1$ and 1 Gy), TGF- $\beta$ and combined radiation-TGF- $\beta$ treatments (scale bars: $20 \mu \mathrm{m}$ )
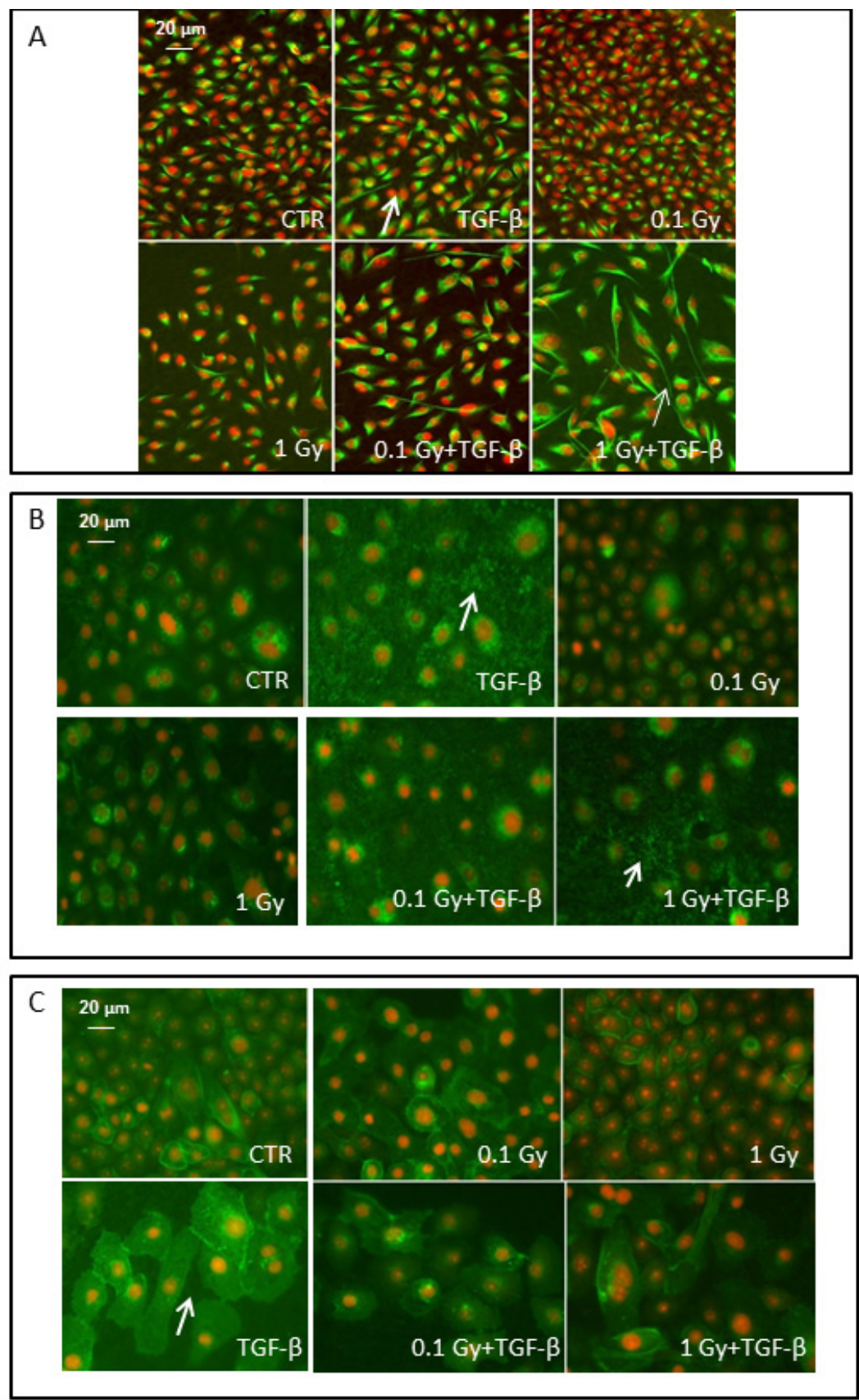


\subsection{Post-irradiation immunoblotting analyses of EMT marker expression in BEAS-2B and HBEC-3KT-cells}

A clear statistically significant induction of fibronectin expression was noticed in the TGF- $\beta$ treated and the double treated (TGF- $\beta+0.1 \mathrm{~Gy}$; TGF- $\beta+1 \mathrm{~Gy}$ ) BEAS-2B cells with both studied radiation doses. The $\alpha$-particle irradiation alone could not induce enhanced expression of the marker (Figure 3(A)). In the HBEC3-KT cells the TGF- $\beta$ treatment was able to induce very low increase in the total amount of cellular fibronectin (Figure 3(C)), although by immunofluorescence staining a re-organisation of the fibronectin filaments in well-developed intracellular network was noticed (Figure 2(B), white arrows). The $\alpha$-particle irradiation only or the double treatment with radiation and TGF- $\beta$ were not able to exert the fibronectin induction, although in the double treated samples there was a trend in the enhancement of the TGF- $\beta$-induced EMT by radiation in the HBEC-3KT cells after moderate doses (1 Gy) (Figure 2(B) and Figure 3(C)).

Figure 3 Analyses of expression of EMT markers post $\alpha$-irradiation in BEAS-2B (A, B) and HBEC-3KT $(C, D)$ cell lines. Western blot analyses of fibronectin $(A$ and $C)$ and E-cadherin (B and D). Error bars - Standard deviation, ${ }^{*} p<0.05$, Student's $t$-test, $(n=3)$

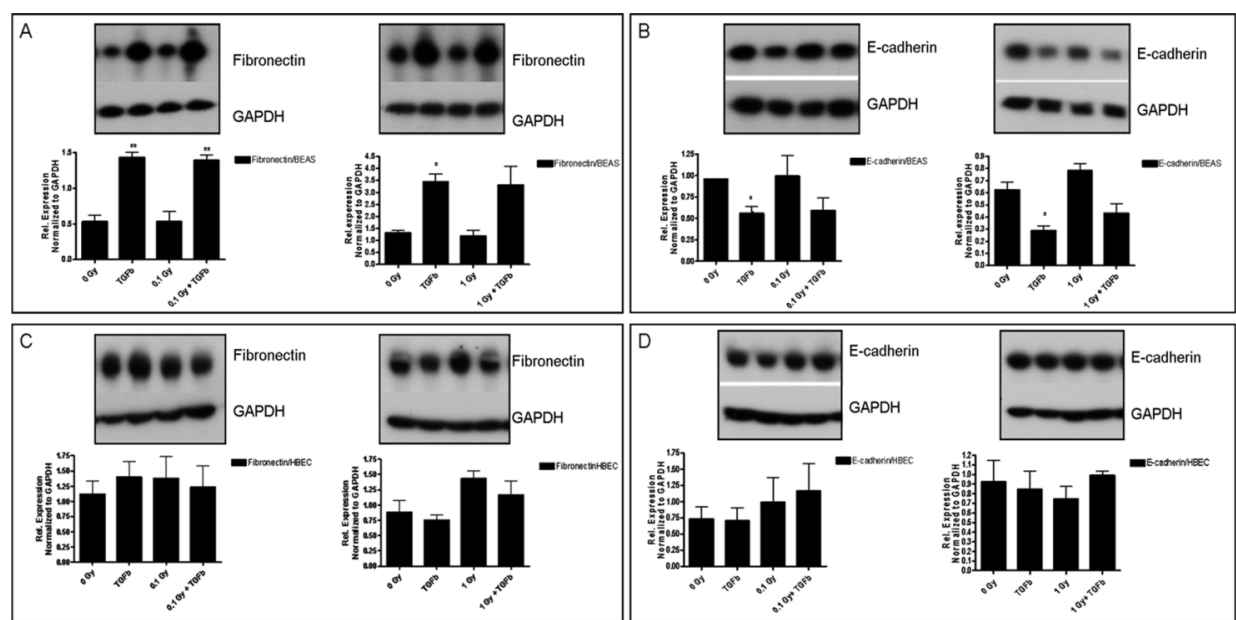

We observed statistically significant decrease in the E-cadherin expression in the TGF- $\beta$ treated BEAS-2B cells (Figure 3(B)). The $\alpha$-particle exposure did not induce additive effect with TGF- $\beta$ on the EMT. There was a minor increase in the E-cadherin expression in the BEAS-2B cells after 1 Gy exposure (Figure 3(B)). For the HBEC-3KT cells there was no such reduction in the epithelial marker expression after the TGF- $\beta$ treatment. Again we detected a trend to increased expression of E-cadherin in the 0.1 Gy irradiated sample and the 0.1 Gy and TGF- $\beta$ treated samples.

In the experiments with $\gamma$-irradiation, the TGF- $\beta$ treatment was able to induce increase in the mesenchymal marker fibronectin levels (Figures 4(A) and 4(C)). However, the results were statistically significant only for the BEAS-2B cells. The epithelial marker E-cadherin was down regulated in the same samples as the results were significant again only in the BEAS-2B cells (Figures 4(B) and 4(D)). The irradiation alone did not have an EMT triggering effect at both applied doses in both cell lines. 
Figure 4 Analyses of expression of EMT markers post $\gamma$-irradiation in BEAS-2B (A, B) and HBEC-3KT (C, D) cell lines. Western blot analyses of fibronectin (A and C) and E-cadherin (B and D). Error bars - Standard deviation, ${ }^{*} p<0.05$, Student's $t$-test $(n=3)$

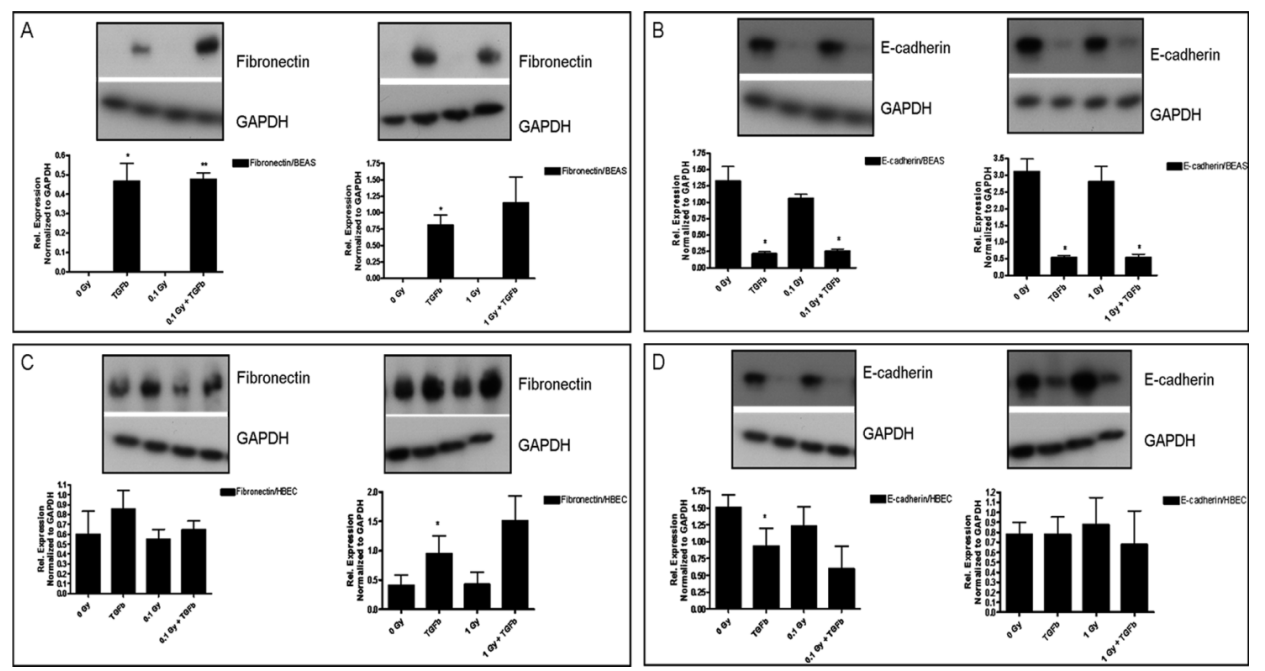

\subsection{Lack of apoptosis induction in both bronchial epithelial cell lines at the applied doses}

To test if the radiation exposure, especially $\alpha$-particles, induces apoptotic death with the applied doses, the M30 CytoDEATH ${ }^{\mathrm{TM}}$ apoptotic assay was performed. Apoptosis could potentially be the reason why neither radiation alone nor in combination with TGF- $\beta$ could enhance EMT induction. The results showed negligible levels of apoptosis at the two doses applied (0.1 and 1 Gy) (Figure 5(A)). However, an increased level of apoptosis was detected with 2 Gy and higher exposures (Figure 5(B)).

\section{Discussion}

The lung tissue is affected by environmental radiation mainly in the form of radon gas $(\alpha$-particles) and also by therapeutic and diagnostic medical radiation exposures $(\gamma$ - and $\mathrm{X}$-rays). The aim of this study was to investigate the potential acute effects of $\alpha$-particles and $\gamma$-radiation on the EMT induction in human lung epithelial cells. The pseudostratified epithelium of the human lung is consisted of multiple cell types with various functions (ciliated, goblet, basal and neuroglandular). During radon inhalation due to the low penetrating ability of the $\alpha$-particles, only the uppermost layer of the epithelium is affected and potentially damaged. There are evidences supporting the involvement of EMT in the development of fibrosis and different types of cancer, including lung cancer (Bartis et al., 2014; Lee and Nelson, 2012; Zavadil and Böttinger, 2005). The EMT has been suggested to increase the invasiveness of already transformed tumour epithelial cells that have survived radiotherapy (Gomez-Casal et al., 2013; Xu et al., 2008). Important role in this process have the EMT-inducing transcription factors Snail, Twist and ZEB1. The group of Gomez-Casal et al. (2013) observed EMT changes (decreased E-cadherin 
and increased $\mathrm{N}$-cadherin and vimentin levels) and activation of Snaill, the major transcription factor involved in the EMT, in surviving irradiated NSCLC cells. In an another study, the up-regulation of ZEB1 has been suggested to play a key role in the accelerated DNA damage response and radioresistance of breast cancer cells (Zhang et al., 2014).

Figure 5 Cytodeath M30 apoptosis staining of BEAS-2A cells after irradiation with low (0.1 Gy) and moderate ( $1 \mathrm{~Gy}$ ) doses of $\alpha$ - and $\gamma$-radiation (A) and of HBEC-3KT cells after irradiation with low (0.1 Gy) and high (2 and 5 Gy) doses of $\alpha$-irradiation (B). Apoptotic cells are stained green (M30). The nuclei are counterstained with propidium iodide (red) (scale bars: $50 \mu \mathrm{m}$ )
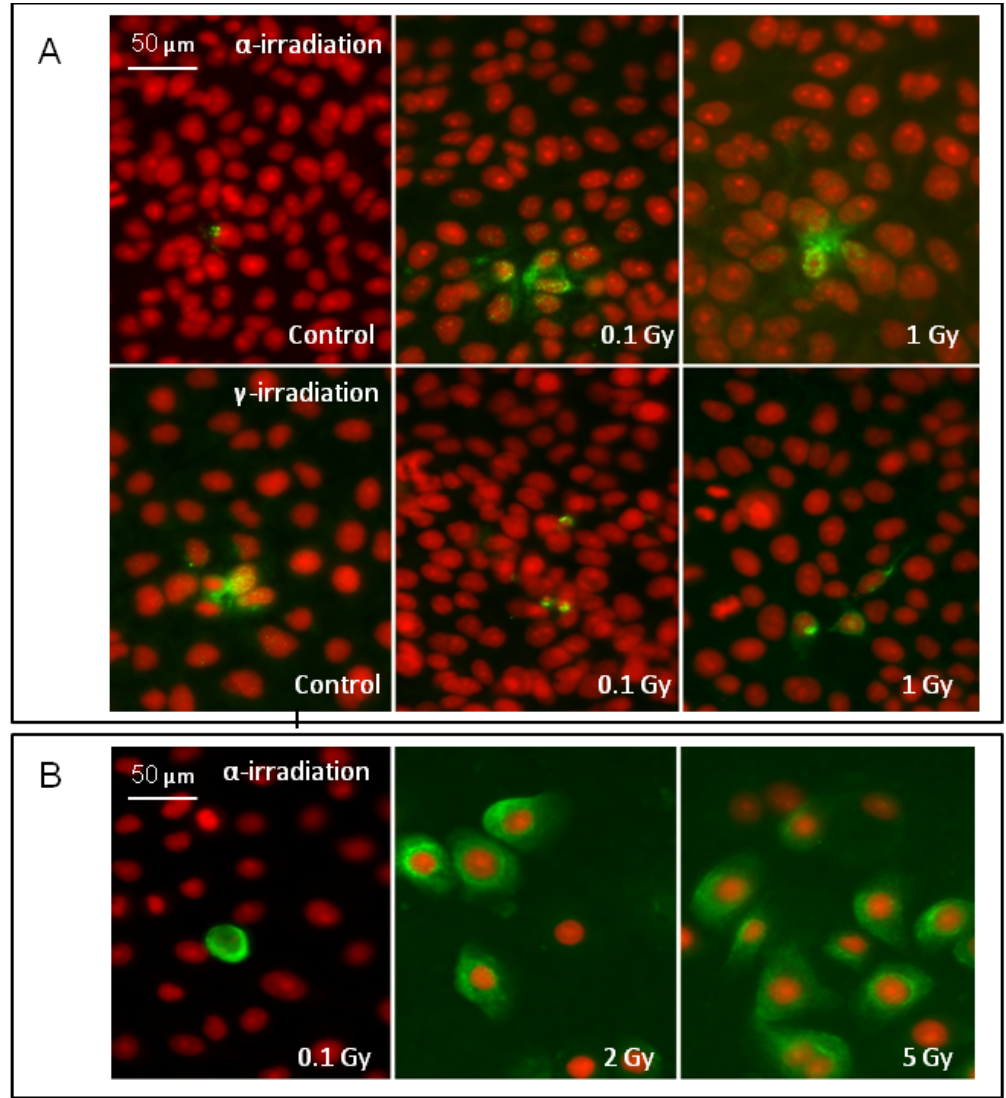

According to our hypothesis a possible step of $\alpha$-particles-induced lung cancer is an EMT transformation of the targeted epithelial cells. However, neither of the applied radiation types $(\alpha-$ or $\gamma$-) alone using single low and moderate exposures was able to induce any changes in the expression of EMT differentiation markers in the analysed cell lines. We used cell cultures with the same confluency in order to avoid the influence of cell density on changes in the cell morphology and cell size. A clear induction of EMT was noticed when the cells were treated with TGF- $\beta$ but no significant additive effect was induced when the cells were exposed to a single radiation dose and TGF- $\beta$ simultaneously. Previously reported characteristics for the EMT process, such as changes in cell shape, 
size, intercellular communication and expression of cell differentiation markers (Câmara and Jarai, 2010; Jia et al., 2014; Prahlad et al., 1998), were observed in both cell lines at the applied TGF- $\beta$ concentrations. The lack of radiation-induced EMT was contrary to previously published observations with other cell types where radiation was able to enhance the TGF- $\beta$-induced EMT in dose- and quality-independent way (Andarawewa et al., 2007; Andarawewa et al., 2011; Wang et al., 2012a; Wang et al., 2012b). Cell typespecific dissimilarities in the TGF- $\beta$ production, response and use of various radiation qualities may explain the controversial results. The doses applied for both low and high LET exposures in this study were comparable to doses used by other research groups (Andarawewa et al., 2007; Andarawewa et al., 2011). Even though we used lower concentration of TGF- $\beta(0.1-0.2 \mathrm{ng} / \mathrm{ml})$ than in the other studies $(0.4 \mathrm{ng} / \mathrm{ml}$ Andarawewa et al., 2007; Andarawewa et al., 2011), it is possible that the lung epithelial cell lines used in our study are highly sensitive to TGF- $\beta$ and this can mask the potential minor effect of radiation exposure to EMT enhancement.

We observed that the BEAS-2B cells were more sensitive to TGF- $\beta$ treatment and EMT induction than the HBEC-3KT cells. For example, the HBEC-3KT cells required doubled TGF- $\beta$ concentration to change morphology and the E-cadherin expression was not reduced to the same levels as in the BEAS-2B cells. This could be due to the use of different methods for immortalisation of these two cell lines. The BEAS-2B line was created by adenovirus-12-SV40 hybrid viral transformation and the cells have been shown to express SV40 T-antigens (Reddel et al., 1993). The SV40 large T-antigen has been linked to cell immortalisation by its binding to tumour suppressor proteins $\mathrm{Rb}$ and p53 which may inhibit important regulatory pathways thus making the cells susceptible to tumourigenesis (Cheng et al., 2009). Part of that process is that the cells may become more prone to TGF- $\beta$-induced EMT (Sato et al., 2013). Although some studies report that the BEAS-2B cell line is non-tumourigenic in nude mice, conditioned media from the same cell line had the ability to change the growth characteristics and induce increased differentiation of normal bronchial epithelial cells. The authors hypothesised that the effect is due to TGF- $\beta$ production from the BEAS-2B cells (Albright et al., 1990). On the other hand, the HBEC-3KT cells that have functional p53, are still able to express contact inhibition and are non-tumourigenic in laboratory animals (Sato et al., 2013). The HBEC$3 \mathrm{KT}$ cells could be regarded as more close to normal epithelial cell model, while the BEAS-2B cells have some characteristics of tumourigenic cells.

Radiation induced apoptosis of targeted cells could be one reason why no cumulative effect of TGF- $\beta$ and radiation exposures were observed in our study. Especially in the case of high LET $\alpha$-particles the targeted cells that are lost via programmed cell death will not go through EMT transition. However, our results excluded apoptosis as a reason for the lack of EMT at the applied doses. Another possible explanation for the lack of EMT might be the different mechanism the low dose $\alpha$-radiation affects the bronchial epithelial cells. Taya et al. (1994) have reported that one of the major effects observed in rat lungs after radon exposure is the local hyperproliferation of epithelial cells. The same group reported increased bromodeoxyuridine (BrdU) incorporation in various areas of the lung as the epithelial cells were more sensitive and the hyperproliferation was occurring in them earlier than in alveolar cells (Taya et al., 1994). EMT may not be the initial step for the directly affected bronchial epithelial cells to respond to radiation.

In contrast to the previously reported data, the E-cadherin expression increased in both cell lines after exposures to ionising radiation, especially at doses of $1 \mathrm{~Gy}$. 
E-cadherin has a very important role in cell adhesion and normal protein levels are necessary to prevent the increased invasiveness and metastatic activity of cancer cell lines (Bongiorno et al., 1995; Bremnes et al., 2002; Paredes et al., 2012). The effect of radiation might be indicative for triggering the intracellular signalling pathways which involve E-cadherin expression in cells. In addition to the adhesion role, the E-cadherin has been described as a responsive element in the wnt $/ \beta$-catenin signaling pathway connected to cell polarisation, cytoskeleton re-organisation and finally to cell migration (Bremnes et al., 2002). However, the specific role of the observed E-cadherin increase in our study has not been studied in detail since the protein changes were not statistically significant and might be only transient cell response.

An important observation in our experimental work was the lack of EMT in the directly targeted epithelial cells. However, it has been suggested that activation of stroma microenvironment, TGF- $\beta$ signalling and EMT induction may have a role in the radiation induced carcinogenesis. We proved that the two bronchial cell lines respond to the TGF- $\beta$ treatment with significant EMT changes. In human lung epithelium microenvironment the surrounding stromal cells could be the source of TGF- $\beta$ signals It has been previously shown in mouse mammary carcinogenesis model used by Barcellos-Hoff et al., that radiation can induce latent TGF- $\beta$ activation and stromal matrix re-organisation in a dosedependent manner with doses as low as 0.1 Gy (Barcellos-Hoff, 1993; Ehrhart et al., 1997). They speculated that irradiation of mesenchymal cells induces features of an activated stroma which further could modify the differentiation state of the neighbouring epithelial cells. In regard to our model, although we could not observe any significant direct EMT effect and TGF- $\beta$ production from the epithelial cells, we obtained data for dose-dependent secretion of active TGF- $\beta$ from lung fibroblast cells post irradiation with $\alpha$-particles (Figure A4). Increased levels of $\alpha$-SMA expression in fibroblast cells have been suggested as one of the markers for tumour-associated fibroblasts or myofibroblasts (Willis et al., 2006; Radisky et al., 2007; De Wever et al., 2008). In our experiments with $\alpha$-particle irradiation, we observed increased levels of $\alpha$-SMA (data not shown), especially after $0.1 \mathrm{~Gy}$ irradiation. The same fibroblast cells exhibited an increased TGF$\beta$ production (Figure A4). These observations were in line with the hypothesis of the important role of fibroblasts for TGF- $\beta$ production and secretion after radiation.

These results are an important step, suggesting again that the direct irradiation of the epithelial cells might not be a sufficient inducer for EMT and there might be a need to investigate the longer term effects from the irradiated microenvironment. Therefore we are planning to explore the role of the radiation-induced signalling from the stromal cells in a co-culture system with epithelial cells in the background of predominantly low-LET radiation.

\section{References}

Albright, C., Jones, R., Hudson, E., Fontana, J., Trump, B. and Resau, J. (1990) 'Transformed human bronchial epithelial cells (BEAS-2B) alter the growth and morphology of normal human bronchial epithelial cells in vitro', Cell Biology and Toxicology, Vol. 6, No. 4, pp.379-398.

Andarawewa, K.L., Costes, S.V., Fernandez-Garcia, I., Chou, W.S., Ravani, S.A., Park, H. and Barcellos-Hoff, M.H. (2011) 'Lack of radiation dose or quality dependence of epithelial-tomesenchymal transition (EMT) mediated by transforming growth factor $\beta$ ', International Journal of Radiation Oncology Biology Physics, Vol. 79, No. 5, pp.1523-1531. 
Andarawewa, K.L., Erickson, A.C., Chou, W.S., Costes, S.V., Gascard, P., Mott, J.D., Bissell, M.J. and Barcellos-Hoff, M.H. (2007) 'Ionizing radiation predisposes nonmalignant human mammary epithelial cells to undergo transforming growth factor $\beta$ Induced epithelial to mesenchymal transition', Cancer Research, Vol. 67, No. 18, pp.8662-8670.

Barcellos-Hoff, M.H. (1993) 'Radiation-induced transforming growth factor beta and subsequent extracellular matrix reorganization in murine mammary gland', Cancer Research, Vol. 53, No. 17, pp.3880-3886.

Barcellos-Hoff, M.H. and Nguyen, D.H. (2009) 'Radiation carcinogenesis in context: How do irradiated tissues become tumors?', Health Physics, Vol. 97, No. 5, pp.446-457.

Bartis, D., Mise, N., Mahida, R.Y., Eickelberg, O. and Thickett, D.R. (2014) 'Epithelialmesenchymal transition in lung development and disease: does it exist and is it important?', Thorax, Vol. 69, No. 8, pp.760-765.

Bongiorno, P.F., Al-Kasspooles, M., Lee, S.W., Rachwal, W.J., Moore, J.H., Whyte, R.I., Orringer M.B. and Beer, D.G. (1995) 'E-cadherin expression in primary and metastatic thoracic neoplasms and in Barrett's oesophagus', British Journal of Cancer, Vol. 71, No. 1, pp.166-172.

Bouquet, F., Pal, A., Pilones, K.A., Demaria, S., Hann, B., Akhurst, R.J., Babb, J.S., Lonning, S.M., DeWyngaert, J.K., Formenti, S.C. and Barcellos-Hoff, M.H. (2011) 'TGF $\beta 1$ inhibition increases the radiosensitivity of breast cancer cells in vitro and promotes tumor control by radiation in vivo', Clinical Cancer Research, Vol. 17, No. 21, pp.6754-6765.

Bremnes, R.M., Veve, R., Hirsch, F.R. and Franklin, W.A. (2002) 'The E-cadherin cell-cell adhesion complex and lung cancer invasion, metastasis, and prognosis', Lung Cancer, Vol. 36, No. 2, pp.115-124.

Câmara, J. and Jarai, G. (2010) 'Epithelial-mesenchymal transition in primary human bronchial epithelial cells is Smad-dependent and enhanced by fibronectin and TNF-alpha', Tissue Repair, Vol. 3, No. 2, doi:10.1186/1755-1536-3-2.

Cheng, J., DeCaprio, J.A., Fluck, M.M. and Schaffhausen B.S. (2009) 'Cellular transformation by Simian Virus 40 and Murine Polyoma Virus T antigens', Seminars in Cancer Biology, Vol. 19, No. 4, pp.218-228.

Darby, S., Hill, D., Auvinen, A., Barros-Dios, J.M., Baysson, H., Bochicchio, F., Deo, H., Falk, R., Forastiere, F., Hakama, M., Heid, I., Kreienbrock, L., Kreuzer, M., Lagarde, F., Mäkeläinen, I., Muirhead, C., Oberaigner, W., Pershagen, G., Ruano-Ravina, A., Ruosteenoja, E., Schaffrath Rosario, A., Tirmarche, A., TomáŠek, L. ,Whitley, E., Wichmann, H.E. and Dol, R. (2005) 'Radon in homes and risk of lung cancer: Collaborative analysis of individual data from 13 European case-control studies', British Medical Journal, Vol. 330, p.223.

De Wever, O., Demetter, P., Mareel, M. and Bracke, M. (2008) 'Stromal myofibroblasts are drivers of invasive cancer growth', International Journal of Cancer, Vol. 123, No. 10, pp.2229-2238.

Ehrhart, E.J., Segarini, P., Tsang, M.L., Carroll, A. and Barcellos-Hoff M.H. (1997) 'Latent transforming growth factor beta1 activation in situ: quantitative and functional evidence after low-dose gamma-irradiation', The FASEB Journal, Vol. 11, No. 12, pp.991-1002.

Ewan, K.B., Henshall-Powell, R.L., Ravani, S.A., Pajares, M.J., Arteaga, C., Warters, R., Akhurst, R.J. and Barcellos-Hoff, M.H. (2002) 'Transforming growth factor- $\beta 1$ mediates cellular response to DNA damage in situ', Cancer Research, Vol. 62, No. 20, pp.5627-5631.

Gomez-Casal, R., Bhattacharya, C., Ganesh, N., Bailey, L., Basse, P., Gibson, M., Epperly, M. and Levina, V. (2013) 'Non-small cell lung cancer cells survived ionizing radiation treatment display cancer stem cell and epithelial-mesenchymal transition phenotypes', Molecular Cancer, Vol. 12, No. 94, doi: 10.1186/1476-4598-12-94.

Hall, E.J. and Brenner, D.J. (2008) 'Cancer risks from diagnostic radiology', The British Journal of Radiology, Vol. 81, pp.362-378.

Hall, E.J. and Giaccia, A.J. (2006) Radiobiology for the Radiologist, 6th ed., Lippincott Williams \& Wilkins. 
Inskip, P.D., Stovall, M. and Flannery, J.T. (1994) 'Lung cancer risk and radiation dose among women treated for breast cancer', Journal of the National Cancer Institute, Vol. 86, No. 13, pp.983-988.

Jia, Y., Wu, D., Yun, F., Shi, L., Luo, N., Liu, Z., Shi, Y., Sun, Q., Jiang, L., Wang, S. and Du, M. (2014) 'Transforming growth factor- $\beta 1$ regulates epithelial-mesenchymal transition in association with cancer stem-like cells in a breast cancer cell line', International Journal of Clinical Experimental Medicine, Vol. 7, pp.865-872.

Kaminska, B., Wesolowska, A. and Danilkiewicz, M. (2005) 'TGF-beta signalling and its role in tumour pathogenesis', Acta Biochimica Polonica, Vol. 52, pp.329-337.

Kim, D.W., Chung, W.K., Shin, D., Hong, S., Park, S.H., Chung, K., Lim, Y.K., Shin, D., Lee, S.B., Lee, H. and Yoon, M. (2013) 'Risk of second cancer from scattered radiation of intensity-modulated radiotherapies with lung cancer', Radiation Oncology, Vol. 8, No. 47, doi:10.1186/1748-717X-8-47.

Lee, K. and Nelson, CM. (2012) 'New insights into the regulation of epithelial-mesenchymal transition and tissue fibrosis', International Review of Cell and Molecular Biology, Vol. 294, pp.171-221.

National Research Council (1999) Biological Effects of Ionizing Radiation (BEIR) VI Report: The health effects of exposure to indoor radon, The National Academies Press, Washington, DC.

Paredes, J., Figueiredo, J., Albergaria, A., Oliveira, P., Carvalho, J., Ribeiro, A.S., Caldeira, J., Costa, Â.M., Simões-Correia, J., Oliveira, M.J., Pinheiro, H., Pinho, S.S., Mateus, R., Reis, C.A., Leite, M., Fernandes, M.S., Schmitt, F., Carneiro, F., Figueiredo, C., Oliveira, C. and Seruca, R. (2012) 'Epithelial E- and P-cadherins: Role and clinical significance in cancer', Biochimica et Biophysica Acta - Reviews on Cancer, Vol. 1826, No. 2, pp.297-311.

Prahlad, V., Yoon, M., Moir, R.D., Vale, R.D. and Goldman, R.D. (1998) 'Rapid movements of vimentin on microtubule tracks: Kinesin-dependent assembly of intermediate filament networks', The Journal of Cell Biology, Vol. 143, No. 1, pp.159-170.

Radisky, D.C., Kenny, P.A. and Bissell, M.J. (2007) 'Fibrosis and cancer: Do myofibroblasts come also from epithelial cells via EMT?', Journal of Cellular Biochemistry, Vol. 101, pp.830-839.

Ramirez, R.D., Sheridan, S., Girard, .L, Sato, M., Kim, Y., Pollack, J., Peyton, M., Zou, Y., Kurie, J.M., DiMaio, J.M., Milchgrub, S., Smith, A.L., Souza, R.F., Gilbey, L., Zhang, X., Gandia, K., Vaughan, M.B., Wright, W.E., Gazdar, A.F., Shay, J.W. and Minna, J.D. (2004) 'Immortalization of human bronchial epithelial cells in the absence of viral oncoproteins', Cancer Research, Vol. 64, No. 24, pp.9027-9034.

Reddel, R.R., Salghetti, S.E., Willey, J.C., Ohnuki, Y., Ke, Y., Gerwin, B.I., Lechner, J.F. and Harris, C.C. (1993) 'Development of tumorigenicity in Simian virus 40-immortalized human bronchial epithelial cell lines', Cancer Research, Vol. 53, No. 5, pp.985-991.

Sato, M., Larsen, J.E., Lee, W., Sun, H., Shames, D.S., Dalvi, M.P., Ramirez, R.D., Tang, H., DiMaio, J.M., Gao, B., Xie, Y., Wistuba, I.I., Gazdar, A.F., Shay, J.W. and Minna, J.D. (2013) 'Human lung epithelial cells progressed to malignancy through specific oncogenic manipulations', Molecular Cancer Research, Vol. 11, No. 6, pp.638-650.

Szőke, I., Farkas, A., Balásházy, I., Hofmann, W., Madas, B. and Szőke, R. (2012) ‘3D-modelling of radon-induced cellular radiobiological effects in bronchial airway bifurcations: direct versus bystander effects', International Journal of Radiation Biology, Vol. 88, No. 6, pp.477-492.

Taya, A., Morgan, A., Baker, S.T., Humphreys, J.A., Bisson, M. and Collier, C.G. (1994) 'Changes in the rat lung after exposure to radon and its progeny: effects on incorporation of bromodeoxyuridine in epithelial cells and on the incidence of nuclear aberrations in alveolar macrophages', Radiation Research, Vol. 139, No. 2, pp.170-177.

Wang, M., Hada, M., Huff, J., Pluth, J.M., Anderson, J., O’Neill, P. and Cucinotta, F.A. (2012a) 'Heavy ions can enhance TGF $\beta$ mediated epithelial to mesenchymal transition', Journal of Radiation Research, Vol. 53, No. 1, pp.51-57.

Wang, M., Hada, M., Saha, J., Sridharan, D.M., Pluth, J.M., Anderson, J., O’Neill, P. and Cucinotta, F.A. (2012b) 'Protons sensitize epithelial cells to mesenchymal transition', PLoS ONE 7: e41249, doi:10.1371/journal.pone.0041249. 
Willis, B.C., duBois, R.M. and Borok, Z. (2006) 'Epithelial origin of myofibroblasts during fibrosis in the lung', Proceedings of the American Thoracic Society, Vol. 3, No. 4, pp.377-382.

World Health Organization (2009) WHO Handbook on Indoor Radon: A Public Health Perspective, Geneva: Available online at: Http://www.Ncbi.Nlm.Nih.gov/books/NBK143216/

Xu, X.G., Bednarz, B. and Paganetti, H. (2008) 'A review of clinical data and radiation dosimetry methods on secondary cancers from external beam radiation treatments', Physics in Medicine and Biology, Vol. 53, No. 13, pp.193-241.

Zavadil, J. and Böttinger, E.P. (2005) 'TGF-beta and epithelial-to-mesenchymal transitions', Oncogene, Vol. 24, No. 37, pp.5764-5774.

Zhang, P., Wei, Y., Wang, L., Debeb, B.G., Yuan, Y., Zhang, J., Yuan, J., Wang, M., Chen, D., Sun, Y., Woodward, W.A., Liu, Y., Dean, D.C., Liang, H., Hu, Y., Ang, K.K., Hung, M., Chen, J. and Ma, L. (2014) 'ATM-mediated stabilization of ZEB1 promotes DNA damage response and radioresistance through CHK1', Nature Cell Biology, Vol. 16, No. 9, pp.864-875.

Zhou, Y., Liu, J., Li, J., Zhang, J., Xu, Y., Zhang, H., Qiu, L., Ding, G., Su, X., Mei-Shi and Guo, G. (2011) 'Ionizing radiation promotes migration and invasion of cancer cells through transforming growth factor-beta mediated epithelial to mesenchymal transition', International Journal of Radiation Oncology Biology Physics, Vol. 81, No. 5, pp.1530-1537. 


\section{Appendix}

Figure A1 DNA damage response of BEAS-2B cells after $\alpha$-particle and $\gamma$-ray irradiations. Immunofluorescence staining showing 53BP1 focus formation for control, $0.1 \mathrm{~Gy}$ and 1 Gy irradiations (scale bars: $20 \mu \mathrm{m}$ )
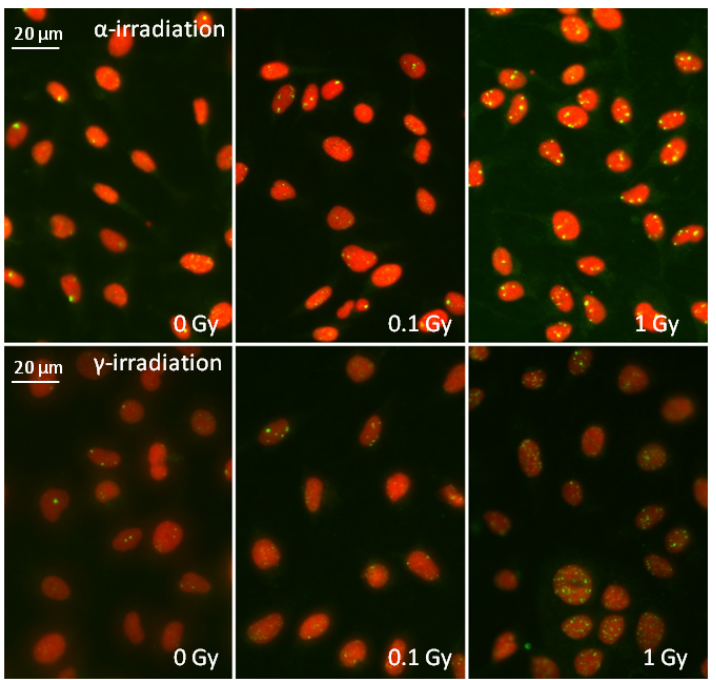

Figure A2 Phase contrast images of HBEC-3KT cells post $\alpha$ - (A) and $\gamma$-irradiation (B) after irradiation only, TGF- $\beta$ and combined TGF- $\beta$ and radiation treatment. Representative images from three independent experiments. White arrows point cells with typical EMT morphology (scale bars: $100 \mu \mathrm{m})$
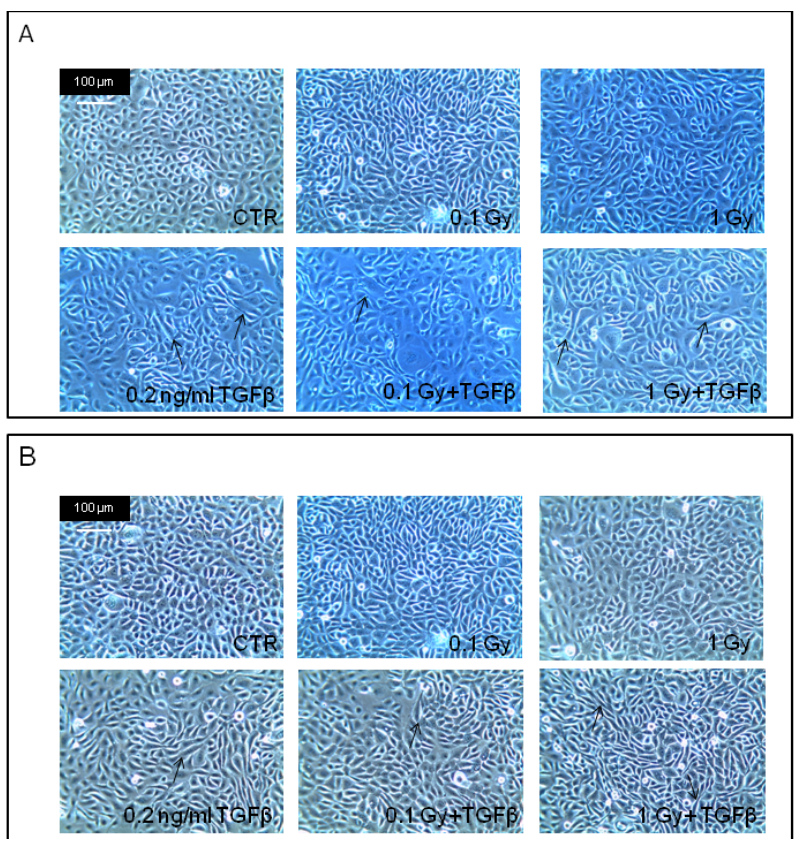
Figure A3 Quantification of the representative immunoblots showed increased expression of fibronectin $(\mathrm{A}, \mathrm{C})$ and decreased expression of E-cadherin (B, D) after TGF- $\beta$ treatment in BEAS-2B (A, B) and HBEC-3KT cells $(\mathrm{C}, \mathrm{D})$

A

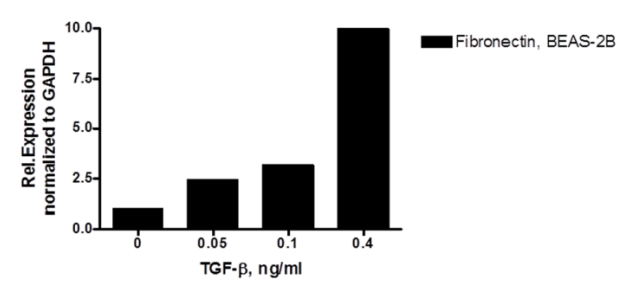

B

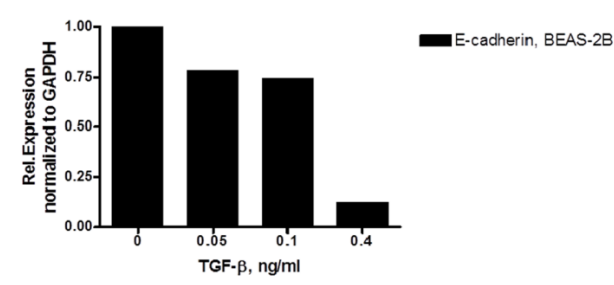

C

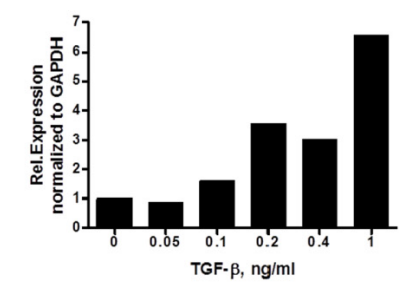

D

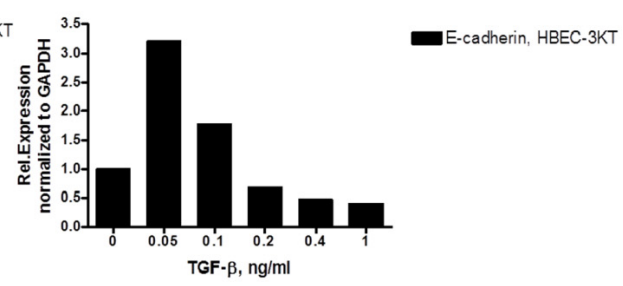

Figure A4 Dose-dependent increase in TGF- $\beta$ expression in MRC-9 normal lung fibroblasts post $\alpha$-particle irradiation shown by Western blot analysis. Bottom graph shows quantification of the representative from two biological repeats
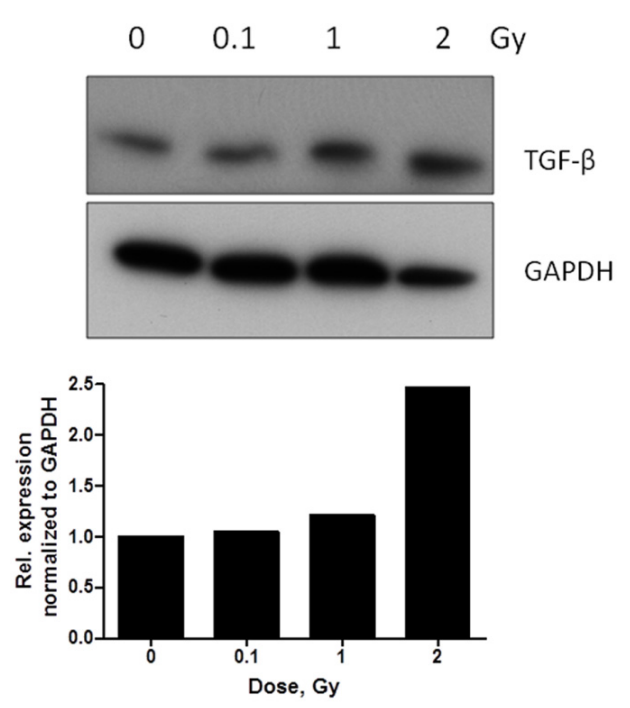